\title{
ANALISIS GAP DALAM PELAKSANAAN CAPACITY BUILDING APARATUR PEMERINTAHAN KECAMATAN SE-KOTA BENGKULU DALAM PELAYANAN PUBLIK
}

\author{
Oleh: \\ Harius Eko Saputra, Evi Lorita \\ Program Studi Ilmu Administrasi Publik Fakultas Ilmu-Ilmu Sosial Universitas \\ Dehasen Bengkulu
}

\begin{abstract}
Walaupun pembangunan kapasitas aparatur pemerintah wajib dilaksanakan, namun pada pelaksanaannya di lapangan belum sesuai dengan yang diharapkan. Berkaitan dengan hal tersebut, penelitian ini bertujuan untuk mengetahui masalah-masalah dalam pelaksanaan capacity building aparatur pemerintah kecamatan se-Kota Bengkulu dalam memberikan pelayanan publik. Metode penelitian menggunakan pendekatan deskriptif kualitatif. Informan penelitian berjumlah 21 orang yang terdiri Camat dan staf kecamatan Kota Bengkulu, masyarakat Kota Bengkulu, dan mahasiswa. Pengumpulan data penelitian menggunakan wawancara, dokumentasi, dan studi pustaka. Hasil penelitian menyimpulkan bahwa dalam pengembangan kapasitas aparatur pemerintah kecamatan se-kota Bengkulu masih terdapat berbagai masalah diantaranya: 1) masih terdapat pegawai tamatan SMA, 2) usia pegawai didominan oleh pegawai dengan kisaran usia 40 tahun keatas, 3) tingkat pendidikan pegawai yang belum mampu untuk menjalankan tupoksi yang ada secara maksimal, 4) sistem kenaikan pangkat yang belum transparan dan masih bersifat administratif, 5) database sudah ada tapi belum maksimal untuk memberikan informasi, 6) serta adanya kelemahan pada pola diklat. Dengan demikian masalah-masalah tersebut akan berdampak pada kurang maksimalnya pelayanan yang diberikan oleh aparaur pemerintah kecamatan kepada masyarakat.
\end{abstract}

\section{Kata Kunci:}

Analisis Gap, Capacity Building, Pelayanan Publik.

\section{PENDAHULUAN}

Dalam rangka mewujudkan tata kelola pemerintahan yang baik (good governance), sumber daya manusia (SDM) menjadi faktor utama yang dapat menuentukan terwujud atau tidaknya sistem good governance tersebut. Salah satu upaya yang dilakukan oleh pemerintah dalam mewujudkan good governance adalah dengan melakukan pengembangan kapasitas SDM aparatur pemerintahan (capacity building). Namun pada pelaksanaanya, capacity building ini masih belum dapat dikelola dengan baik. Hal itu ditunjukkan oleh masih sulitnya mengubah cara pikir (mindset) dan cara kerja aparatur, masih rendahnya disiplin dan etika pegawai, sistem karier yang belum sepenuhnya berdasarkan prestasi kerja, sistem remunerasi yang belum memadai untuk hidup layak, rekrutmen yang belum dilakukan berdasarkan kualifikasi pendidikan yang dibutuhkan, penyelenggaraan pendidikan dan pelatihan (diklat) yang belum sepenuhnya dapat meningkatkan kinerja, lemahnya pengawasan dan audit terhadap kinerja aparatur, dan sistem informasi manajemen kepegawaian yang belum berfungsi secara optimal (BAPPENAS, 2007). Akibat dari berbagai persoalan tersebut adalah, pelaksanaan 
pelayanan publik yang efisien dan efektif, yaitu cepat, tepat, murah, dan transparan, belum dapat diwujudkan.

Faktor yang menyebabkan rendahnya kinerja birokrasi disebabkan oleh beberapa sebab, seperti simpang siurnya perundang-undangan yang mengatur bidang kepegawaian; merajalelanya 'spoil system' dalam penerimaan (recruitment), pengangkatan, penempatan dan promosi pegawai; tidak adanya data statistik yang akurat tentang jumlah pegawai negeri yang menimbulkan kesukaran dalam kebijaksanan di bidang kepegawaian; sistem penilaian yang tidak obyektif; pendidikan dan pelatihan yang tidak terarah; banyaknya instansi yang turut campur tangan dalam memecahkan masalah kesejahteraan pegawai; dan pendapatan pegawai negeri yang rendah yang membawa implikasi pada rendahnya kegairahan kerja dan sukarnya menegakkan disiplin pegawai, (Siagian, 1996).

Untuk itu, dalam rangka meningkatkan kinerja pemerintah daerah, maka faktor pengembangan kapasitas aparatur menjadi sangat penting untuk dilaksanakan. Di samping untuk merespon tingginya tuntutan masyarakat terhadap kinerja pemerintah daerah, capacity building aparatur tidak bisa dilepaskan dengan keinginan pemerintah untuk menjalankan good governance yang diarahkan untuk mempraktekkan tata kelola pemerintahan yang ideal.

Dalam Keban (2011) menyatakan bahwa salah satu isu sentral good governance, yaitu adanya perubahan kapasitas aparatur pemerintah dalam merespon dan memperjuangkan kepentingan masyarakat berdasarkan koridor institusi yang ada. Hal tersebut dapat berarti bahwa good governance harus didukung oleh dua aspek utama, yaitu masyarakat dan Negara (pemerintah). Aspek yang pertama direpresentasikan oleh dua arena, masyarakat sipil dan masyarakat ekonomi. Masyarakat sipil berarti bahwa semua warga negara berhak mengontrol penyelenggaraan yang dilakukan pemerintah. Sementara aspek yang kedua direpresentasikan oleh birokrasi dan lembaga politik (political office). Aspek inilah yang sering menjadi sorotan, terutama mengenai birokrasi yang di dalamnya termasuk SDM aparatur.

Bagi sebagaian besar masyarakat sebagai pengguna pelayanan publik oleh pemerintahan, yang menjadi pertanyaan pokok yang selalu muncul adalah, sampai seberapa besar keberhasilan capacity building aparatur dalam mendukung reformasi birokrasi, khususnya di dalam pembangunan, pelaksanaan fungsi pemerintahan dan pemberian pelayanan publik. Karena pada kenyataanya, masyarakat dapat melihat sendiri melalui media massa tentang kinerja pemerintahan yang selalu digambarkan sebagai ketidakmampuan, kelemahan, dan kejahatan dari berbagai pihak, mulai dari eksekutif, legislatif dan yudikatif.

Di ranah pemerintahan, Pengembangan kapasitas SDM (capacity building) aparatur merupakan program andalan reformasi birokrasi dan telah mulai dilaksanakan sejak Pemerintahan Orde Baru berakhir, akan tetapi fakta di lapangan belum banyak membawa pengaruh. Pelaksanaannya dilatar belakangi oleh berbagai faktor, di antaranya: tingginya praktek korupsi, kolusi dan nepotisme (KKN); tingkat kualitas pelayanan publik yang belum mampu memenuhi harapan publik; tingkat efisiensi, efektifitas dan produktivitas yang belum optimal; tingkat transparansi dan akuntabilitas yang masih rendah; serta tingkat disiplin dan etos kerja pegawai yang masih rendah.

Berdasarkan hasil penilaian Kementerian Dalam Negeri (Kemendagri) selama tahun 2016 dan diumumkan tahun 2018 diketahui bahwa Provinsi Bengkulu berada di urutan ke-32 dari 33 Provinsi se-Indonesia dalam Kinerja Penyelenggaraan Pemerintahan (termasuk didalamnya pelayanan publik). Mengenai anjokloknya kinerja hingga berada di peringkat ke32 tersebut, Plt. Gubernur Provinsi Bengkulu Dr. Drh. H. Rohidin Mersyah, M.MA mengatakan bahwa "Memang ada beberapa hal yang perlu diperbaiki untuk meningkatkan 
kinerja pemerintahan kita. Salah satunya dengan memperbaiki pelayanan publik." (Harian Rakyat Bengkulu.Com, 30 April 2018).

Dari berbagai masalah tentang pelaksanaan capacity building di berbagai instansi pemerintahan di atas, peneliti merasa perlu untuk menganalisis permasalahan capacity building yang dihadapi pemerintahan kecamatan di Kota Bengkulu dalam memberikan pelayanan publik.

\section{METODE PENELITIAN}

Penelitian ini menggunakan metode penelitian deskriptif kualitatif yang bertujuan untuk mendeskripsikan dan menganalisis fenomena, peristiwa, aktivitas sosial, sikap, kepercayaan, persepsi, pemikiran orang secara individual maupun kelompok. Data yang digunakan dalam penelitian ini adalah data primer yang bersumber dari hasil wawancara peneliti kepada informan penelitian. Data sekunder penelitian ini adalah bersumber dari dokumen-dokumen resmi yang terdapa di lokasi penelitian yang berkaitan dengan fokus penelitian. Informan penelitian ini adalah aparatur kecamatan Kota Bengkulu yang terdiri dari 13 orang informan. Pemilihan informan enggunakan teknik purposive sampling atau sampel bertujuan. Tahap analisa data menggunakan triangulasi data yaitu melakukan reduksi data, sajian data dan penarikan kesimpulan.

\section{HASIL PENELITIAN DAN PEMBAHASAN}

Pengembangan kapasitas memiliki multi makna, dan interpretasinya tergantung pada siapa yang menggunakan dan dalam konteks apa. Secara umum, yang dipahami adalah bahwa pengembangan kapasitas merupakan suatu konsep yang terkait erat dengan pendidikan, pelatihan dan pengembangan sumberdaya manusia. Namun, pemahaman konven- sional mengenai konsep pengembangan kapasitas telah berubah selama beberapa tahun terakhir, di mana pengembangan kapasitas dipahami secara lebih luas dan holistik, yang mencakup aspek sosial, organisasi dan pendidikan (Enemark, 2006).

Pengembangan kapasitas melalui intervensi pada level sistem, institusi, dan individu merupakan upaya yang multidimensi. Oleh karena itu, perencanaannya harus ditetapkan dalam tahapan waktu yang rasional: jangka pendek, jangka menengah, dan jangka panjang. Selanjutnya, pada setiap tahapan harus ditetapkan prioritas- prioritasnya. Prioritas pertama dari semua tahapan tersebut adalah membuat kebijakan dan peraturan pendukung, yakni penjabaran operasional dari framework otonomi daerah berdasarkan Undang- Undang Nomor 32/2004 dan Undang-Undang Nomor 33/2004 yang wujudnya adalah penyesuaian dan modifikasi semua perangkat peraturan perundangan organik berupa kebijakan Daerah seperti Perda dan Keputusan Kepala Daerah, yang dapat menciptakan sistem yang efektif dan efisien untuk mencapai tujuan. Semua kebijakan dan peraturan tersebut harus jelas menggambarkan sistem dan mekanisme prosedural yang melibatkan semua level tersebut. Prioritas berikutnya adalah menangani permasalahan yang terjadi dalam hubungan antar unit dan antar sektor, (Ginting dan Daeli, 2012).

Berdasarkan data lapangan, jumlah pegawai kecamatan di Kota Bengkulu adalah sebanyak 117 orang. Data pada sekretariat di 9 (Sembilan) Kecamatan, menunjukkan bahwa tingkatan pendidikan formal aparat Kecamatan didominasi oleh Sarjana, diikuti oleh SMA serta Sarjana Muda. Data pada tabel berikut, menggambarkan tingkatan pendidikan formal aparat Kecamatan di Kota Bengkulu, keadaan 2018. 
Tabel 1.

Tingkat Pendidikan Formal Aparat Kecamatan Kota Bengkulu Keadaan 2018

\begin{tabular}{|l|l|c|c|c|c|c|}
\hline \multirow{2}{*}{ No } & \multirow{2}{*}{ Kecamatan } & \multicolumn{4}{|c|}{ Tingkat Pendidikan } & \multirow{2}{*}{$\begin{array}{c}\text { Jumlah } \\
\text { Pegawai }\end{array}$} \\
\cline { 3 - 6 } & & S2 & S1 & D3 & SMA & 15 \\
\hline 1 & Ratu Agung & 3 & 7 & 1 & 4 & 14 \\
\hline 2 & Ratu Samban & 1 & 6 & 1 & 6 & 9 \\
\hline 3 & Teluk Segara & 1 & 8 & - & - & 18 \\
\hline 4 & Singgaran Pati & 1 & 6 & 2 & 9 & 14 \\
\hline 5 & Sungai Serut & - & 10 & - & 4 & 20 \\
\hline 6 & Muara Bangkahulu & - & 13 & 1 & 6 & 9 \\
\hline 7 & Gading Cempaka & 1 & 6 & 2 & - & 9 \\
\hline 8 & Selebar & - & 7 & - & 2 & 9 \\
\hline 9 & Kampung Melayu & - & 8 & 1 & - & $\mathbf{1 1 7}$ \\
\hline T o t a l & $\mathbf{7}$ & $\mathbf{7 1}$ & $\mathbf{8}$ & $\mathbf{3 1}$ & \\
\hline
\end{tabular}

Sumber : Hasil Penelitian 2018

Data pada tabel di atas memberikan gambaran bahwa tingkat pendidikan formal aparat 9 (Sembilan) Kecamatan di Pemerintahan Kota Bengkulu dapat dikatakan baik, karena 86 dari 117 Pegawai Negeri Sipil memiliki tingkat pendidikan formal sarjana. Hal ini dibenarkan pula oleh Kasubdit Diklat Kepemimpinan Agus Harryansyah, SE, pada wawancara tanggal 9 April 2018, menurutnya bahwa:

"Jika dilihat dari tingat pendidikan formal, maka aparat kantor Camat ini boleh saya katakan baik, karena lebih banyak menamatkan pendidikan sarjana/S1 dan S2 semua kepala subbagian dan kepala seksi adalah sarjana bahkan sudah ada sarjana S2 dan nampak sangat berpengaruh terhadap kinerja aparat dalam melaksanakan tugas mereka masing-masing. Spesifikasi kesarjanaan yang dimiliki aparat juga berbeda, ada Sarjana Hukum, Sarjana Sosial .Sarjana Ilmu Pemerintahan, Sarjana Ekonomi dan beberapa lagi, sehingga nampak ada keanekaragaman dan berpengaruh pada pemahaman mereka tentang tugas yang diemban."

Walaupun upaya pembangunan kapasitas telah dimulai sejak Peraturan Walikota untuk para Camat, namun demikian, nampak bahwa upaya kearah yang diharapkan dalam rangka pengembangan pelayanan publik dan pengembangan kemampuan individu masih jauh dari yang diharapkan. Dari hasil penelitian pada Kantor di 9 (Sembilan) Kecamatan Kota Bengkulu menunjukkan rendahnya, bahkan belum dilaksanakan DIKLAT penjenjangan bagi aparatur Kecamatan, juga masih kurang dilakukannya bentuk-bentuk pembinaan dan pelatihan bagi aparatur kecamatan dan kepada subbagian dan Seksi dalam menjalankan tugas profesinya. Kondisi ini tentunya sangat berpengaruh bagi kemampuan kapasitas apartur kecamatan dalam menjalankan tugas-tugas pemerintahan maupun dalam memberikan pelayanan kepada masyarakat.

Kondisi ini tentunya akan sangat mempengaruhi kinerja aparat dalam menghasilkan kualitas pelayanan yang diharapkan oleh masyarakat. Berdasarkan hasil wawancara dengan beberapa masyarakat yang sering menerima pelayanan dari aparat pemerintah, nampak kemampuan aparat belum maksimal. Menurut Efriyandi seorang Mahasiswa Universitas Dehasen saat mengurus surat-surat di Kantor Kecamatan Teluk Segara, mengatakan bahwa: 
"Secara umum saya melihat bahwa kemampuan aparat belum terlalu optimal; hal ini nampak pada tingkat pengetahuan mereka terhadap sesuatu urusan yang harus diselesaikan; kadang lamban dan sering meminta petunjuk untuk menyelesaikan tugas dimaksud; mungkin karena belum terlalu memahami hal-hal yang baru diterapkan, sehingga butuh waktu untuk menyesuaikan diri; tetapi bagi masyarakat, kecepatan pelayanan, kemampuan petugas, tanggung jawab dan kedisiplinan dalam menyelesaikan tugas adalah sangat penting."

Hal yang sama dikemukakan oleh Drs. Khairus Saleh, Tokoh masyarakat Kampung Kelawi Kecamatan Sungai Serut , menyatakan bahwa:

"Kelihatannya ada pegawai yang kurang siap untuk bekerja, sehingga jika ada pegawai yang dibutuhkan karena tugasnya tidak masuk kantor karena berhalangan, maka urusan-urusan masyarakat tidak dapat dilayani, menunggu sampai pegawai yangbersangkutan masuk kerja. Bagi masyarakat kecepatan pelayanan sangat penting, jadi seharusnya ad pegawai yang disiapkan untuk mengantisipasi jika pegawai yang bersangkutan tidak masuk kantor. Selain itu, tingkat kesopanan pegawai juga harus dijaga, kadang-kadang ketika masyarakat membawa persyaratan yang tidak lengkap untuk mengurus surat-surat tertentu diperlakukan kurang baik."

Sehubungan dengan permasalahan dalam pengembangan kapasitas (capacity building) pada aparatur kecamatan Kota Bengkulu yang telah dipaparkan di atas, berikut merupakan hasil analisis peneliti yang membagi pokok-pokok permasalahan tersebut menjadi enam faktor pengahambat, yaitu:

1. Masih terdapat pegawai tamatan SMA.

Berdasarkan hasil penelitian dan dapat dilihat pada tabel 1 diketahui bahwa untuk tingkat pendidikan aparatur kecamatan Kota Bengkulu masih terdapat pegawai yang tingkat pendidikannya masih rendah, dalam hal ini setingkat SLTA ke bawah. Di sisi lain, meskipun sebagian ada pegawai yang sudah berpendidikan sarjana, namun jumlah pegawai berpendidikan pasca sarjana masih sangat minim dibandingkan dengan total jumlah pegawai.

Tabel 2.

Persentase Tingkat Pendidikan Formal Aparat Kecamatan Kota Bengkulu Keadaan 2018

\begin{tabular}{|c|l|c|c|}
\hline No. & Tingkat Pendidikan & Jumlah Pegawai & Persentase \\
\hline 1. & S2 & 7 & $5,98 \%$ \\
\hline 2. & S1 & 71 & $60,68 \%$ \\
\hline 3. & D3 & 8 & $6,83 \%$ \\
\hline 4. & SMA & 31 & $26,49 \%$ \\
\hline \multicolumn{2}{|c|}{ Total } & $\mathbf{1 1 7}$ & $\mathbf{1 0 0 \%}$ \\
\hline
\end{tabular}

Sumber : Hasil Penelitian 2018

Tabel 2 di atas merupakan data persentase tingkat pendidikan formal aparatur kecamatan Kota Bengkulu tahun 2018. Berdasarkan data di atas diketahui bahwa aparatur/pegawai kecamatan Kota Bengkulu didominasi oleh pegawai dengan tingkat pendidikan setingkat S1 dengan jumlah 71 orang atau 60,68\%. Sedangkan untuk pendidikan S2 hanya berjumlah 7 orang atau 5,98\%. Untuk tingkat pendidikan SMA 
masih cukup banyak dengan jumlah 31 orang atau 26,49\% lebih besar dibandingkan pendidikan D3 yang hanya berjumlah 8 orang atau $6,83 \%$.

2. Usia pegawai didominan oleh pegawai dengan kisaran usia 40 tahun keatas.

Berdasarkan hasil penelitian ini jumlah pegawai usia produktif (20-40 tahun) lebih sedikit dibandingkan dengan pegawai usia mendekati non produktif (40 tahun ke atas). Hal ini pada dasarnya cukup mempengaruhi tingkat/kinerja pegawai dalam memberikan pelayanan kepada masyarakat.

3. Tingkat pendidikan pegawai yang belum mampu untuk menjalankan tupoksi yang ada secara maksimal.

Berdasarkan tabel 2. Di atas diketahui bahwa jumlah pegawai dengan pendidikan SMA masih cukup banyak yakni berjumlah 31 orang atau 26,49\%, sedangkan untuk tingkat pendidikan S2 hanya 7 orang atau 5,98\%. D3 berjumlah 8 orang atau $6,83 \%$ dan S1 berjumlah 71 orang atau $60,68 \%$. Berdasarkan data tersebut dan hasil wawancara serta observasi yang telah dilakukan diketahui berdasarkan tingkat pendidikan pegawai tersebut belum mampu mendukung pencapaian tupoksi secara maksimal, karena pembagian tugas belum dilakukan berdasarkan tingkat dan latar belakang pendidikan sehingga dapat mempengaruhi pelayanan yang diberikan.

4. Sistem kenaikan pangkat yang belum transparan dan masih bersifat administratif.

Sistem kenaikan pangkat yang diberlakukan selama ini masih bersifat administratif dan belum dikaitkan dengan prestasi kerja yang dihasilkan pegawai. Penyebab lainnya adalah, kelemahan sistem pengukuran kinerja, sehingga pegawai yang berprestasi kurang mendapat perhatian dan penghargaan yang adil. Pegawai yang prestasi kerjanya tidak bagus masih memungkinkan untuk naik pangkat/golongan. Kemudian, ada juga ketidaksesuaian antara kompetensi dengan pekerjaan yang diemban, karena pada saat rekrutmen, kebutuhan yang diinginkan oleh Pemda tidak sesuai dengan ketersediaan yang ada di masyarakat. Hal lainnya, pengembangan jabatan fungsional masih diabaikan oleh Pemda, padahal melalui jabatan fungsional dapat dikembangkan profesionalisme SDM aparatur.

5. Database sudah ada tapi belum maksimal untuk memberikan informasi.

Hasil penelitian menunjukan bahwa dalam pengembangan kapasitas (capacity building) aparatur kecamatan Kota Bengkulu sudah ada pengembangan database pegawai, namun pada pelaksanaannya database tersebut belum mampu sepenuhnya menghasilkan informasi yang cepat, tepat, dan akurat.

6. Adanya kelemahan pada pola diklat.

Kemudian dari sisi diklat, beberapa kelemahan pola diklat yang dilaksanakan antara lain:

(1) Sistem diklat yang ada baru terfokus pada diklat penjenjangan, diklat fungsional dan diklat teknis, dimana itupun belum tertangani dengan baik dan masih dalam taraf perbaikan menyeluruh,

(2) Training needs belum dapat dimanfaatkan untuk menghasilkan pola diklat yang sistemik dan berbasis kompetensi,

(3) Desain diklat, kurikulum dan jam pelatihan belum mengacu pada standar kompetensi yang dibutuhkan,

(4) Spesialisasi instruktur dan widyaiswara masih terfokus pada aspek manajemen, dan 
(5) Belum mempertimbangkan kesesuaian antara kompetensi pegawai dengan kompetensi jabatan yang akan datang. Untuk itu perlu disiapkan pola diklat yang dapat mendukung pola karir pegawai.

Berdasarkan hasil penelitian dan analisa peneliti di atas tentang analisis gap (masalah) dalam pelaksanaan capacity building aparatur pemerintahan kecamatan se-Kota Bengkulu dalam pelayanan publik digambarkan sebagai berikut:

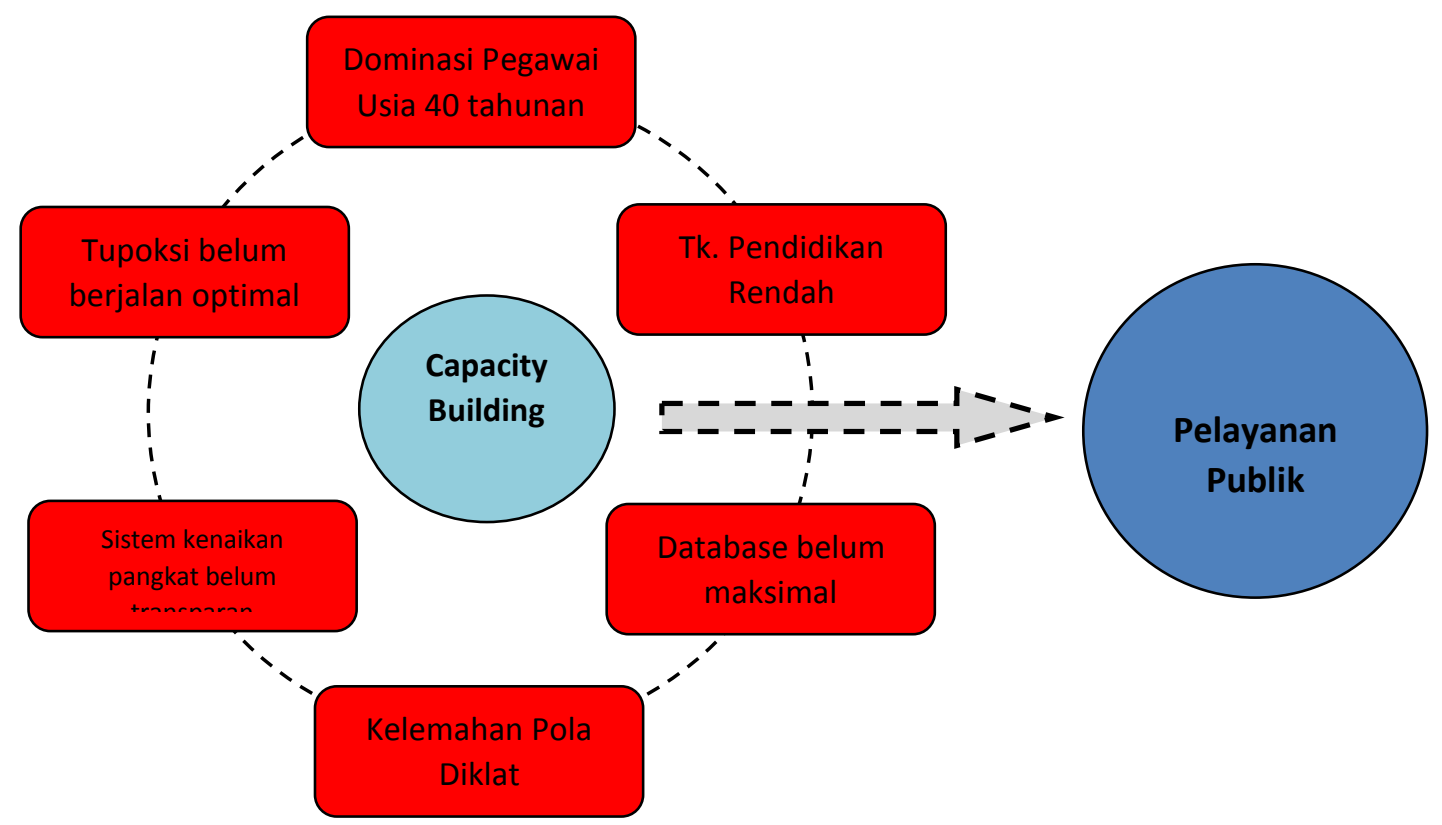

Gambar 1. Analisa Masalah Capacity Building Aparatur Kecamatan Kota Bengkulu

Gambar 1. di atas merupakan pola/gambar pelaksanaan pengembangan kapasitas (capacity building) aparatur Kecamatan Kota Bengkulu. Berdasarkan gambar tersebut di atas dapat dilihat indikator-indikator masalah yang terdiri dari enam indikator yang dapat menghambat pelaksanaan capacity building aparatur kecamatan di Kota Bengkulu. Terhambatnya pelaksanaan capacity building tersebut pada akhirnya akan berdampak lemahnya pelayanan publik yang diberikan aparatur/pegawai kecamatan kepada masyarakat Kota Bengkulu.

Temuan tersebut menunjukkan bahwa meskipun manajemen pembinaan pegawai pada umumnya telah merujuk pada Undang-Undang Nomor 43/1999 beserta peraturan pelaksanaannya, namun implementasi Undang-Undang tersebut di lapangan mengindikasikan berbagai permasalahan yang kompleks sejak dari peraturan perundang-undangan hingga ke pengelolaan pegawai. Di samping itu, pelaksanaan diklat selama ini sangat monoton, terutama dari segi substansi atau materi diklat. Sebagian besar materi Diklatpim Tingkat IV dan Diklatpim Tingkat III hampir sama. Di lingkungan Pemda Kota Bengkulu, keterbatasan anggaran merupakan salah satu kendala utama dalam penyelenggaraan diklat PNS.

\section{KESIMPULAN}

Berdasarkan hasil penelitian dan pembahasan yang telah diuraikan, maka dapat ditarik kesimpulan bahwa dalam pengembangan kapasitas aparatur pemerintah kecamatan se-kota Bengkulu masih terdapat berbagai masalah diantaranya: 1) masih terdapat pegawai tamatan SMA, 2) usia pegawai didominan oleh pegawai dengan kisaran usia 40 tahun keatas, 3) tingkat 
pendidikan pegawai yang belum mampu untuk menjalankan tupoksi yang ada secara maksimal, 4) sistem kenaikan pangkat yang belum transparan dan masih bersifat administratif, 5) database sudah ada tapi belum maksimal untuk memberikan informasi, 6) serta adanya kelemahan pada pola diklat. Dengan demikian masalah-masalah tersebut akan berdampak pada kurang maksimalnya pelayanan yang diberikan oleh aparaur pemerintah kecamatan kepada masyarakat.

\section{SARAN}

1. Dengan melihat berbagai persoalan masyarakat yang senantiasa muncul di KecamatanKecamatan, seperti masalah ketenagakerjaan, pemukiman dan perdagangan, dan lainlain maka sudah selayaknya dipikirkan pengisian jabatan Fungsional di Kecamatan oleh aparat yang memiliki kompetensi guna menyelesaikan persoalan dimaksud.

2. Manajemen Pelayanan publik yang saat ini dilakukan aparat Pemerintah Kecamatan, hendaknya disesuaikan dengan model Indeks Kepuasan Masyarakat berdasarkan Keputusan Menteri PAN Nomor: Kep/25/M.PAN/2/2004, Tentang Pedoman Umum Penyusunan Indeks Kepuasan Masyarakat unit Pelayanan Instansi Pemerintah. Penyesuaian ini diperlukan karena mengandung unsur-unsur kepuasan masyarakat secara umum dan diharapkan dalam pelaksanaannya dapat meningkatkan kualitas pelayanan sebagaimana yang dikehendaki masyarakat.

\section{DAFTAR PUSTAKA}

Amri, Agus Suryono dan Suwondo. 2009. Pengembangan Sumberdaya Aparatur Sebagai Upaya Meningkatkan Kinerja: Studidi Kantor Sekretariat Daerah Kabupaten Sumbawa, WACANA, Vol. 12 No.3 Juli 2009.

Bogdan, Robert dan Steven J Taylor, 1993, Kualitatif Dasar-Dasar Penelitian diterjemahkan oleh A Khozin Affandi, Usaha Nasional, Surabaya, Indonesia.

Eade, D. 1998. Capacity Building: An Approach to People-Centered Development, Oxford, UK: Oxfam, GB. Edralin, J.Sl. 1997. The New Local Governance and Capacity Building: A Strategic Approach, Regional Development Studies, Vol.3, p.148-150.

Enemark, Stig. 2006. Capacity Building for Institutional Development in Surveying and Land Management, paper presented in the Promoting Land Administration and Good Governance, 5th FIG Regional Conference Accra, Ghana, March 8-11, 2006.

Fitzsimmons, James A, and Mona J. Fitzsimmons, 1994. Service management for competitive advantage, McGraw - Hill, Inc, New York.

Giroth,L.M, 2004. Status dan Peran Pendidikan Pamong Praja Indonesia. Indra Prahasta, Bandung.

Ginting, Yosep dan Daeli, Sorni Paskah. 2012. Pengembangan Kapasitas Aparatur Pemerintah Daerah Di Era Otonomi (Studi Kasus: Pemerintah Daerah Kabupaten Samosir). Jurnal Bina Praja. Volume 4 No. 2 Juni 2012: 105 - 116.

Hanif, Nurcholis. 2005. Pengembangan Kapasitas Pemda: Upaya Mewujudkan Pemda yang Menyejahterakan Masyarakat, Jurnal Organisasi dan Manajemen, Voume. 1, Nomor 1, September 2005.

LAN RI, 1997. Sistem Administrasi Negara RI, Jilid I, Edisi Ketiga, PT Gunung Agung, Jakarta.

--, 2004. Reformasi dan Performansi Pamong Praja, Indra Prahasta, Bandung

Mardiasmo dan Halim Abdul, 1999. Prinsip-prinsip dalam Manajemen Pembiayaan Desentralisasi, FE- UGM Yogyakarta. 
Miles, BB, dan AM Hubberman, 1992. Analisis Data Kualitatif, UI Press, Jakarta.

Modeong, S dan Wirman Syafri, 2002. Hubungan kerja Kecamatan dan Desa, Alqa Print Jatinangor, Bandung.

Moleong, Lexy J, 2001, Metodologi Penelitian Kualitatif, PT Remaja Rosdakarya, Bandung.

Nawawi, Hadari, 1998, Metodologi Penelitian Bidang Sosial, Cetakan Ke delapan, Gadjah Mada University Press, Yogyakarta.

Ndraha, Taliziduhu, 1997. Budaya Organisasi, PT Rineka Cipta, Jakarta.

Ndraha, T, 2000. Pembangunan Desa dan AdministrasiPemerintahaan Desa, Yayasan Karya Dharma IIP, Jakarta. -1997. Kajian awal Birokrasi Pemerintah dan Politik Orde Baru, Yarsif Watampone, Jakarta.

Siagian,S.P. 1997. Organisasi, Kepemimpinan dan Perilaku Administrasi, Toko Gunung Agung, Jakarta.

Singarimbun.M, dan Efendi Sofyan, 1989. Metodologi Penelitian Survey, LP3S, Jakarta.

Supratno, 1997. Pengukuran tingkat Kepuasan pelanggan untuk menaikkan pangsa pasar, Rineka Cipta Jakarta.

Supriatna,T, 2000. Administrasi Birokrasi dan Pelayanan Publik, Nimas Multima, Jakarta.

Tjiptono, Fandi, 1997. Manajemen Jasa, Andi Yogyakarta.

Sadu Wasistiono, Sadu, 2003. Manajemen Pemerintah Daerah (kapita selekta), Fokusmedia, Bandung.

Siagian,S.P,2003, Teori dan Praktek Kepemimpinan (cetakan kedua), Rineka Cipta, Jakarta.

Robbins, Stephen P, 1994, Teori Organisasi : Struktur, Desain dan Aplikasi, Ahli Bahasa Jusuf Udaya, Arcan, Jakarta.

Wahab, Solichin Abdul, 2002, Analisis Kebijaksanaan : Dari formulasi ke Implementasi Kebijaksanaan Negara, Bumi Aksara, Jakarta

Wicaksono, Bambang, 2004, Krisis Birokrasi di Era Otonomi Daerah, Pusat Studi Kependudukan dan Kebijakan ,UGMYogyakarta.

\section{Peraturan Perundang-Undangan dan Dokumen lainnya.}

Undang-Undang Nomor 23 Tahun 2014 tentang Pemerintah Daerah.

Keputusan Menteri PAN Nomor : Kep/25/M.PAN/2/2004, Tentang Pedoman Umum Penyusunan Indeks Kepuasan Masyarakat unit Pelayanan Instansi Pemerintah.

Peraturan Walikota Nomor 10 Tahun 2016 Tentang Pembentukan dan Susunan Perangkat Daerah Kota Bengkulu.

Peraturan Walikota Bengkulu Nomor 58 Tahun 2016 Tentang Uraian Tugas dan Fungsi Kecamatan dan Kelurahan di Lingkungan Pemerintahan Daerah Kota Bengkulu.

Bahan Presentasi Temuan dan Rekomendasi BAPPENAS, Tentang Pengkajian Kebutuhan Pengembangan Kapasitas Pemerintah Daerah, Nopember 2000.

LP3ES, 2002. Modul Pengembangan Kapasitas NGO/OMS, Jakarta.

Nofi, Hasanudin, 2015. Jurnal, Pengembangan sumber daya manusia aparatur pemerintah daerah (studi pada Badan Kepegawaian Daerah Kabupaten Jember), Jember.

Soeprapto, HR Riyadi, Heru Ribawanto, Iman Hanafi, 2008. Jurnal, Pengembangan Sumber Daya Aparatur Daerah di Era Reformasi (Kasus di Kabupaten Trenggalek),hhtp//pustakaonline.wordpress.com/2008/03/22/.

Soewandi, Made, 2003. Makalah, Konsep dasar penentuan kewenangan wajib dan Standar Pelayanan Minimal (SPM), Jakarta. 